Natasha Sajé

\title{
Czytanie późnego Henry’ego Jamesa
}

DOI: http://dx.doi.org/10.12775/LC.2017.011

jest jak uprawianie seksu, będąc przywiązaną do łóżka.

$\mathrm{Z}$ rozpostartymi rękami i nogami, bierzesz, co daje,

ufając mu na tyle, by oczekiwać,

że będzie łaskawy, niespieszny. A jednak

trudno to nazwać zabawą:

Zdania długie na całą stronę więżą

kostki i ocierają nadgarstki.

Frazy swędzą jak napuchnięte miejsca po ukąszeniu pszczoły

albo zawieszają cię w przerwie

między atakami migreny,

pulsująca niebieska mgła

ustępuje. Kręcisz się i wijesz -

gdybyś była rozcięta w pól,

czy zdołałby całkiem wejść?

Kiedy nalegasz, by szybciej się ruszal,

pominął drobiazgi,

doszedł do tej dobrej części, strofuje:

„Wszystkie części są dobre”.

Wtedy zdajesz sobie sprawę, że krępuje cię

nieuniknione rozczarowanie i zaczynasz

się wyplątywać,

sięgając obok jego mięsistych białych palców

po własne pióro.

Przekład Mirosława Buchholtz 